\title{
Association between interleukin gene polymorphisms and multiple myeloma susceptibility
}

\author{
MUHAMAAD NAVEED SHAHZAD ${ }^{1}$, IQRA IJAZ ${ }^{2}$, SYED SHAH ZAMAN HAIDER NAQVI ${ }^{3}$, \\ CHENG YAN $^{1}$, FANLI LIN ${ }^{1}$, SHUTAN LI ${ }^{1}$ and CHUNLAN HUANG ${ }^{1}$ \\ ${ }^{1}$ Stem Cell Laboratory, Department of Hematology; ${ }^{2}$ Sino-German Department for The Treatment of Ovarian Tumors, \\ The Affiliated Hospital of Southwest Medical University; ${ }^{3}$ Department of Diabetes and Endocrinology, \\ The Affiliated Hospital of Southwest Medical University, Luzhou, Sichuan 646000, P.R. China
}

Received December 7, 2018; Accepted June 10, 2019

DOI: $10.3892 / \mathrm{mco} .2020 .1979$

\begin{abstract}
The present study performed a retrospective observational study in order to investigate the relationship between the interleukin family gene polymorphisms and risk of multiple myeloma (MM), based on sixteen case-control studies that contained 2,597 patients with MM and 3,851 controls. The results demonstrated that the genotypes IL-6 and IL-1 GG increased the risk of MM by approximately 40.8 and $80.2 \%$ compared with the genotypes AA and $\mathrm{CC}$ [odds ratio $(\mathrm{OR})=1.14,95 \%$ confidence interval $(\mathrm{CI})$, $0.88-1.47$, and $\mathrm{OR}=1.16,95 \% \mathrm{CI}, 0.61-2.19$; respectively]. The results also revealed a significant association between $\mathrm{T}: \mathrm{C}$ polymorphism of the IL-6 and IL-10 and the risk of MM (TC/CC: $\mathrm{OR}=1.37,95 \% \mathrm{CI}, 0.88-2.16$ and TT/CC: $\mathrm{OR}=1.26$, 95\% CI, 0.77-2.06, respectively). Additionally, no significant association was identified between the $\mathrm{C}$ :A polymorphisms of the IL-6 (rs8192284) and IL-10 (rs1800872) receptors and the overall risk of $\mathrm{MM}(\mathrm{P}>0.05)$. G:C polymorphisms of the IL-1 $\beta 1464 \mathrm{G}>\mathrm{C}$ and IL-6572G $>\mathrm{C}$ significantly increased the risk of $\mathrm{MM}(\mathrm{P}<0.05)$. However, it has been determined that there is a significant association between the C:T polymorphism of the IL- $1 \alpha-889 \mathrm{C}>\mathrm{T}$ and IL-1 $\beta-3737 \mathrm{C}>\mathrm{T}$ and the risk
\end{abstract}

Correspondence to: Professor Chunlan Huang, Stem Cell Laboratory, Department of Hematology, The Affiliated Hospital of Southwest Medical University, 25 Taiping Street, Luzhou, Sichuan 646000, P.R. China

E-mail: chunlanhuang01@gmail.com

Abbreviations: MM, multiple myeloma; IL, interleukin family; HWE, Hardy-Weinberg equilibrium; NOS, Newcastle-Ottawa scale; PRISMA, Preferred Reporting Items for Systematic Reviews and Meta-Analysis; QUADAS-2, Quality Assessment of Diagnostic Accuracy Studies 2; SD, standard deviation; ORs, odds ratios; CIs, confidence intervals; PCR-RFLP, polymerase chain reaction-restriction fragment length polymorphism; SNP, single nucleotide polymorphism

Key words: interleukin family gene polymorphisms, multiple myeloma, prognosis, systematic review of MM $(\mathrm{P}<0.001)$. Subgroup analysis revealed that the detection of $\mathrm{G}$ :A polymorphisms in the IL- 6 promoter $(\mathrm{OR}=1.05$, 95\% CI, 0.78-1.44) is more accurate in MM samples of the Asian population $(\mathrm{OR}=1.24,95 \% \mathrm{CI}, 0.92-1.74)$. In addition, no significant association was identified between the IL gene polymorphisms in MM samples categorized by ethnicity and the IL family type $(\mathrm{P}=0.27)$. These single nucleotide polymorphism loci may be the appropriate gene markers for gene screening and a promising therapeutic strategy in the prognostics of patients with MM.

\section{Introduction}

Multiple myeloma (MM) is a common neoplastic disorder (1). It is the second most diagnosed hematological malignancy in China with the incidence rate of $\sim 1.1 / 100,000$ that accounts for $2.1 \%$ of all new cancer cases in 2016 (2). Typically, MM is an incurable cancer of the plasma cells, which is identified by the infiltration and clonal proliferation of antibody-secreting post-germinal center plasma cells in the bone marrow that lead to renal insufficiency, bone disease and anemia $(3,4)$.

Recent articles have indicated that age, male sex, obesity and ionizing radiation exposure are the most common risk factors for MM $(5,6)$. Nevertheless, the exact cause of MM is still unknown (6). Epidemiological studies have shown an increasing incidence rate of MM in Caucasian countries. Although African populations have the highest incidence rate of MM, while the lowest ones belong to the Asian and Mediterranean populations $(7,8)$.

The pathology of MM is speculated to involve multiple factors including genetic, immune system and environmental causes. Since MM is a heterogeneous disease, genetic factors play an important role in its etiology (9). Gene polymorphisms of inflammatory factors may be involved in the progression of MM by unbalancing pro- and anti-inflammatory cytokines profile $(9,10)$.

Interleukin (IL) family that are involved in the immune response and inflammatory processes of MM, consist of a group of lymphatic factors with a multiplicity of biological activities $(11,12)$. Many experimental evidences have revealed specific associations between the metastatic risk of MM and activation of interleukin (12). In light of this, among the 
interleukin family, IL-6 with its receptor IL-6R is the major interleukin for the $\mathrm{T}$ helper (Th) mediated inflammation and it is important in maintaining the Th1/Th2 balance in the inflammatory stage of MM $(13,14)$. These observations indicate that human IL-6 and IL-10 polymorphisms might act as a biomarker for monitoring the clinical course of MM $(15,16)$. Consequently, the prognostic value of genetic factors are potentially limited in genotype-related interleukin, specific interleukin loci and individual phenotype (14).

Recently, a multivariable analysis was used to determine if interleukin family polymorphisms are a prognostic factor for survival in MM patients (17-19). It has been widely reported that many different polymorphisms in different loci are related to poor survival and prognosis of MM $(19,20)$. The polymorphism of interleukin family occurs in MM patients, and it is associated with statistically increased of MM risk (20-22). Interleukin production is regulated by the polymorphisms of cytokine genes in promoter regions $(20,23)$. The high level of pro-inflammatory interleukin level is a significant predictor of both progression-free survival (PFS) and overall survival (OS) in Caucasian MM patients $(24,25)$.

Although, the results of these studies are controversial or inconclusive due to their limited genuine heterogeneity, stage of MM and sample size. Therefore, we conducted a quantitative systematic review along with a comprehensive meta-analysis investigation to resolve inconsistent and often ambiguous findings. Hence, this paper attempted to investigate the associations between the interleukin family gene polymorphisms and MM patients.

\section{Materials and methods}

Ethics statement. The present meta-analysis was approved by an independent Ethics Committee/institutional review board at Southwest Medical University, Department of Hematology in Luzhou, China. This investigation was carried out by following recommendations of the Preferred Reporting Items for Systematic Reviews and Meta-Analysis (PRISMA) (26).

Search strategy and study identification. A comprehensive literature search was conducted in MEDLINE electronic databases of PubMed, Embase, Wiley Online Library, Web of Science, Science Direct and VIP-Google Scholar Database. All databases were searched without using language restrictions to assess the prognostic value of interleukin family polymorphism in MM patients prior to July 05, 2018, with no lower date limit. The search string was conducted by using MeSH terms and following the main heading term or word (both the US and UK variants). Based on the research question, the combinations of the keywords or main headings were determined as follows: 'IL' OR 'interleukin', OR 'IL-' AND 'polymorphism' OR 'polymorphisms' OR 'interleukin polymorphisms' OR 'single nucleotide polymorphism' OR 'SNP', AND 'myeloma' OR 'multiple myeloma'. We have repeated these terms for each of the investigated interleukins, including: IL- $1 \alpha / \beta,-4,-6,-10,-17,-21,-23,-26$ and their receptors. Alternative synonyms and spellings were incorporated using Boolean 'OR' and the main terms were linked with Boolean 'AND'.
Inclusion/exclusion criteria. The following inclusion standards were used to select potential studies for this meta-analysis: i) Evaluated association between the individual IL and/or the IL receptor polymorphism with MM risk; ii) Human genotypes involvement iii) Use of a case-control design; iv) Contained raw genotype frequencies for at least one IL promoter and/or IL receptor polymorphism; v) Publication in English. All case reports, retrospective studies, editorials and review articles, family-based studies, unrelated articles, studies without available genotype frequencies, studies that only investigated the impact of IL polymorphisms in response to therapy or drug resistance and genome-wide association studies were excluded. When an author had published several articles with data obtained from the same patient population, only the newest or the most informative article was selected.

Data collection. The titles and abstracts of all selected articles were analyzed according to the PICO principle by two independent investigators (MNS and II) (27). Any disagreement or discrepancy was adjudicated through debate or consultation; if a consensus was not reached then a third investigator $(\mathrm{SH})$ was consulted. The electronic study was supplemented by a hand-search of relevant articles from reference lists to ensure that all relevant research were identified. Synchronously, references of review articles were checked for any relevant articles and bibliographies. The following key components of all qualified studies were recorded: First author's name, year of publication, ethnicity, country of origin, genotyping methods, sample size, characteristics of controls and matching criteria, study design, TNM stage, clerk stage, reference control, total number of cases and controls that were stratified by genotype frequencies (homozygous wild-type, heterozygous and homozygous mutant), P-value for Hardy-Weinberg equilibrium (HWE) of controls and true and false positives and negatives. We also e-mailed the corresponding authors of the selected articles to obtain additional and/or any missing information, as well as the copies of the original data required for the meta-analysis. Finally, if the above information was not mentioned in the original study or we did not receive any response via email, the item was preserved as 'not reported (NR)'.

Quality assessment. The quality of the included studies were assessed by two authors $(\mathrm{CY}$ and $\mathrm{CH})$, independently according to the Newcastle-Ottawa Scale (NOS) (28) and Quality Assessment of Diagnostic Accuracy Studies 2 (QUADAS-2) (29). Low-quality studies with scores of 4 or lower were excluded. Additionally, the risk of bias was calculated according to criteria from the Cochrane Collaboration's tool (Cochrane Handbook for Systematic Reviews of Interventions Version 5.1.0.).

Statistical analysis. The systematic search was performed using Review Manager Software version 5.2 (The Nordic Cochrane Centre, Copenhagen, Denmark). The RevMan version 5.2 was used to combine data (free software was downloaded from http://www.cochrane.org, The Cochrane Collaboration, The Nordic Cochrane Centre, Copenhagen, Denmark, 2012). Data were presented as means \pm standard deviation (SD) or median (range), and a description of qualitative variables as 


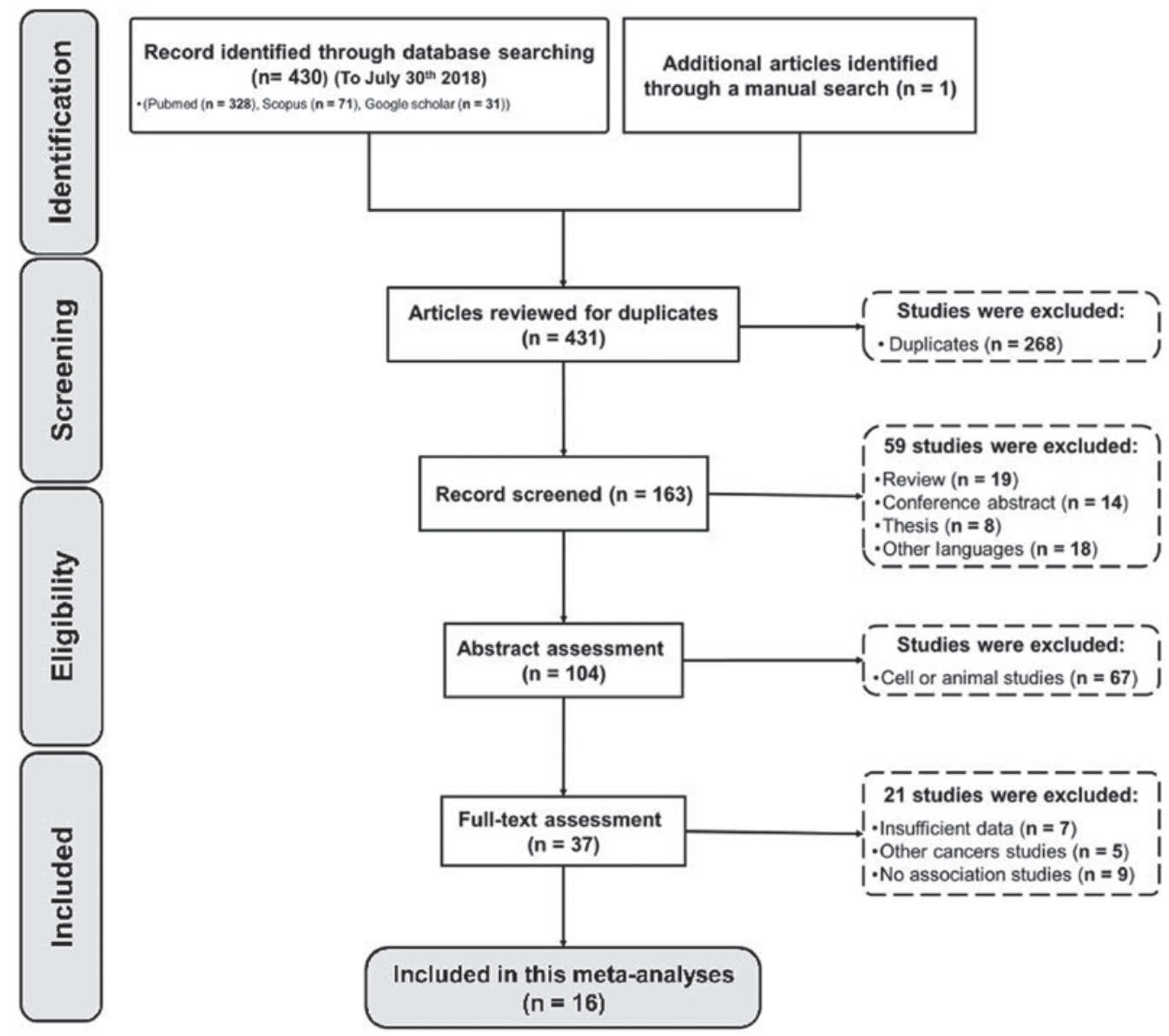

Figure 1. Flowchart of the study selection in the meta-analysis (following PRISMA guidelines, $\mathrm{n}=$ number of studies).

number and percentage. HWE was checked by $\chi^{2}$ test (30). The results of the meta-analysis were reported as odds ratios (ORs) with $95 \%$ confidence intervals (CIs). The ORs were pooled for each allele comparison in the three models, the dominant model, the recessive model and heterozygote model. The Chi-square-based Q-test was applied to testify between-study heterogeneity. Hazard ratio (HR) was calculated by the fixed effects model when $\mathrm{P}$ (heterogeneity) $>0.05$, as a secondary analysis. Otherwise, the random-effects model was used. According to our hypothesis and inclusion criteria, HR $>1$ implies poor prognosis for any IL polymorphisms. We used pooled HRs with $95 \%$ CIs to find the relationship between IL single nucleotide polymorphisms (SNPs) and MM susceptibility. The Hazard ratios and $95 \%$ CIs were calculated by Tierney's method if the data were not reported in the original paper. Furthermore, subgroup analysis was conducted for the type of each allele polymorphisms and ethnicity, genotyping methods, IL type and reference control. Publication bias was evaluated by Begg's funnel plots and Egger's regression test (31). A value of 'Pr>|z|' less than 0.05 was considered as potential publication bias (32). Moreover, we also conducted a sensitivity analysis by precluding a single study to observe whether the pooled HRs changed. Statistical analyses were conducted using Meta-DiSc version 1.4 and R software Packages (version 3.3.1), included 'mada' (for sensitivity and specificity analysis). $\mathrm{P}<0.05$ and $\mathrm{I}^{2}>50 \%$ was considered as statistically significant.

\section{Results}

Study selection. A detailed PRISMA flowchart of the study identification, screening and exclusion process are shown in Fig. 1. A total of 431 studies were retrieved by database searching, with 340 potentially eligible studies that met the inclusion and exclusion criteria and 1 record attained through manual search. By screening the titles, 268 studies were excluded due to being duplicated. After carefully reviewing abstracts, 126 studies were excluded including conference studies, review articles, thesis compilations, those that were not either in English or Chinese, cell culture and animal studies data. Of the remaining 37 full-text candidate articles, 21 potential studies were excluded involving insufficient data, other cancer studies and unrelated studies. Finally, 16 studies were selected and presented in the current meta-analysis that attempts to find a relationship between interleukin polymorphism and risk of MM.

Study and SNP characteristics. The main characteristics of the included studies are shown in Table I. The published dates of all research studies varied from 2000 to 2018. Most of the research was conducted within Caucasian communities: 10 studies in Caucasian populations $(62.5 \%)(20,22,23,25,33-38), 3$ within Asian populations $(18.75 \%)(17,39,40)$ and 3 in Mixed Afro-American populations $(18.75 \%)(24,41,42)$. Of note, the quantitative TaqMan method (TaqMan PCR) was often used 
Table I. Summary of included articles.

\begin{tabular}{|c|c|c|c|c|c|c|c|c|}
\hline $\begin{array}{l}\text { First } \\
\text { author }\end{array}$ & Year & $\begin{array}{c}\text { Population } \\
\text { (ethnicity) }\end{array}$ & $\begin{array}{l}\text { Genotyping } \\
\text { method }\end{array}$ & $\begin{array}{c}\text { Sample size } \\
\text { (case/control) }\end{array}$ & $\begin{array}{c}\text { Source } \\
\text { of control }\end{array}$ & Sex & $\begin{array}{l}\text { NOS } \\
\text { score }\end{array}$ & (Refs.) \\
\hline Zheng & 2000 & Sweden (C) & PCR-RFLP & $73 / 129$ & PB & Not matched & 7 & (33) \\
\hline Zheng & 2001 & Sweden (C) & PCR-RFLP & $73 / 109$ & PB & Not matched & 7 & (34) \\
\hline Mazur & 2005 & Poland (C) & Taq-PCR & $54 / 50$ & PB & Matched & 8 & (23) \\
\hline Cozen & 2006 & $\mathrm{USA}(\mathrm{C}, \mathrm{M})$ & Taq-PCR & $146 / 125$ & PB & Matched & 8 & (24) \\
\hline Duch & 2007 & $\operatorname{Brazil}(\mathrm{C}, \mathrm{M})$ & Taq-PCR & $52 / 60$ & $\mathrm{~PB}$ & Matched & 9 & (41) \\
\hline $\begin{array}{l}\text { Abazis- } \\
\text { Stamboulieh }\end{array}$ & 2007 & Greece $(\mathrm{C})$ & Taq-PCR & $74 / 160$ & HB & Not matched & 8 & (22) \\
\hline Aladzsity & 2009 & Hungary (C) & $\begin{array}{l}\text { Taq-PCR and } \\
\text { PCR-RFLP }\end{array}$ & $100 / 99$ & & & 8 & (35) \\
\hline Birmann & 2009 & USA (C) & Taq-PCR & $82 / 164$ & PB & Not matched & 8 & $(20)$ \\
\hline Martino & 2012 & $\begin{array}{l}\text { Italy and } \\
\text { Germany }(\mathrm{C})\end{array}$ & Taq-PCR & $201 / 234$ & PB & Matched & 9 & (38) \\
\hline Vangsted & 2012 & Denmark (C) & Taq-PCR & $348 / 1,700$ & PB & Matched & 8 & $(36)$ \\
\hline Stephens & 2012 & $\mathrm{USA}(\mathrm{C}, \mathrm{M})$ & Taq-PCR & $626 / 44$ & PB & Not matched & 8 & (42) \\
\hline Iakupova & 2003 & Russia (C) & Taq-PCR & $69 / 102$ & PB & Not matched & 9 & $(25)$ \\
\hline Chakraborty & 2017 & India (A) & Taq-PCR & $103 / 117$ & HB & Matched & 8 & (39) \\
\hline Kasamatsu & 2017 & Japan (A) & PCR-RFLP & $128 / 202$ & PB & Matched & 9 & $(40)$ \\
\hline Nielsen & 2017 & Denmark (C) & Taq-PCR & $348 / 355$ & $\mathrm{HB}$ & Not matched & 7 & (37) \\
\hline Kasamatsu & 2018 & Japan (A) & PCR-RFLP & $120 / 201$ & PB & Matched & 8 & (17) \\
\hline
\end{tabular}

PCR, polymerase chain reaction; PCR-RFLP, polymerase chain reaction-restriction fragment length polymorphism; Taq-PCR, Taq man Real time polymerase chain reaction; PB, population-based; HB, hospital-based; C, Caucasian; A, Asian; M, Mixed Afro-Americans; NOS, Newcastle-Ottawa scale.

to detect the SNP state with control references (11 studies, $68.75 \%)(20,22-25,36-39,41,42)$. Also, polymerase chain reaction-restriction fragment length polymorphism (PCR-RFLP) method was used in 5 studies $(31.25 \%)(17,33-35,40)$. The variables from sixteen relevant case-control studies were contained 2,597 cases and 3,851 controls. Source controls were mainly selected by population-based method with age/sex-matched (12 studies, 75\%) (17,20,23-25,33,34,36,38,40-42). Regarding the NOS methodological quality, all included studies were of high quality with $\geq 7$ out of 10 (mean 8.02 point).

The genotype susceptibility of MM and interleukin family gene polymorphisms are shown in Table SI. In Total, 16 published studies had detected interleukin polymorphism of IL-1 $\beta$, IL-1 $\alpha$, IL-4, IL-6, IL-6R, IL-10, IL-10R, IL-17 and IL-23 in the prediction of MM patients. In more details, 2 studies had identified the relationship between the SNP of IL- $1 \alpha / \beta(22,36)$, one study of IL- 437 , ten studies of IL- 6 and IL-6R $(20,22-25,34,37-39,42)$, four studies of IL-10 and IL-10R $(17,23,33,37)$, three studies of (IL-17 39-41) and one IL-23R polymorphisms 17 . The majority of SNP associations were reported by Birmann et al (20). IL-6 promoter was the most frequently reported (11 of 16 datasets; $68.75 \%$ ) involving 1,854 MM patients and 1,479 controls in 5 different SNPs. The IL-6 promoter rs1800795 $(174 \mathrm{G}>\mathrm{C})$ was the most frequently reported SNP of the IL-6 promoter ( 9 of all SNPs; $81.82 \%$ ). Furthermore, A:G (10 of 33 SNPs; $30.3 \%$ ) and C:T (11 of 33 SNPS; $33.4 \%$ ) substations are the most reported SNP allies in this meta-analysis. The genotypic frequencies of the controls in these 16 studies were all consistent with the HWE (Table SI).

Quality assessment. All 16 selected papers were methodologically assayed by NOS and QUADAS-2 quality evaluation standards of the Cochrane Reviewers' Handbook. The detailed quality assessment of eligible studies, according to the NOS score, was summarized in Table SII. Overall, all studies included in the current meta-analysis were judged to be at moderate to high risk of bias, with scores $\geq 7$ points (Table SII). The average NOS score was 8.01 out of 10 , that was relatively classified in the high quality. Many studies provided sufficient information about study design and execution. Also, QUADAS-2 results confirmed that significant bias were not present in this meta-analysis. Fig. 2 shows all parameters of QUADAS-2 assessment, regarding bias risk and applicability concerns. Most studies had an acceptable range with regard to completeness of outcome data (attrition bias) and other sources of bias. More than half of the included studies were rated as low risk for most parameters of the bias risk $(48.84 \%)$ and applicability concerns (62.5\%). As shown in Fig. 2, no signification bias (Fig. 2A) and applicability concerns (Fig. 2B) were found in any of the selected studies.

The outcome of the meta-analysis. The present meta-analysis was performed in the both homozygous and heterozygous allele genetic model. Based on our systematic approach, we tried to find the associations between the MM risk and SNP of G:A, G:C and T:C in IL-1 $\beta$, IL-1 $\alpha$, IL-4, IL-6, IL-6R, IL-10, 


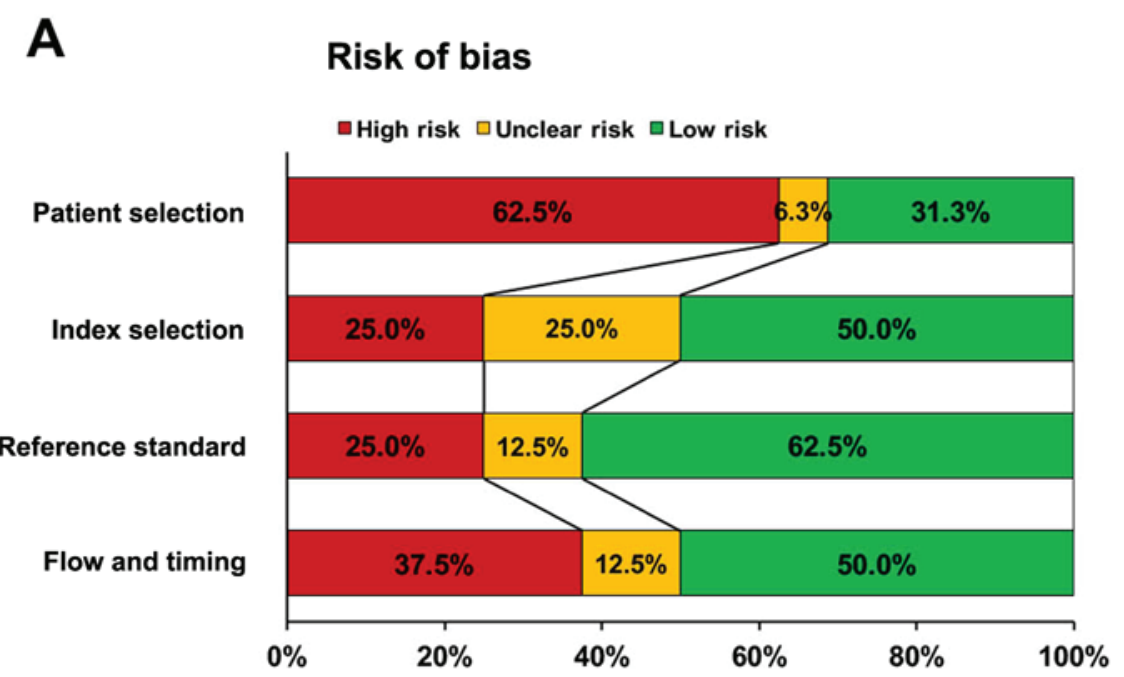

B

\section{Applicability concerns}

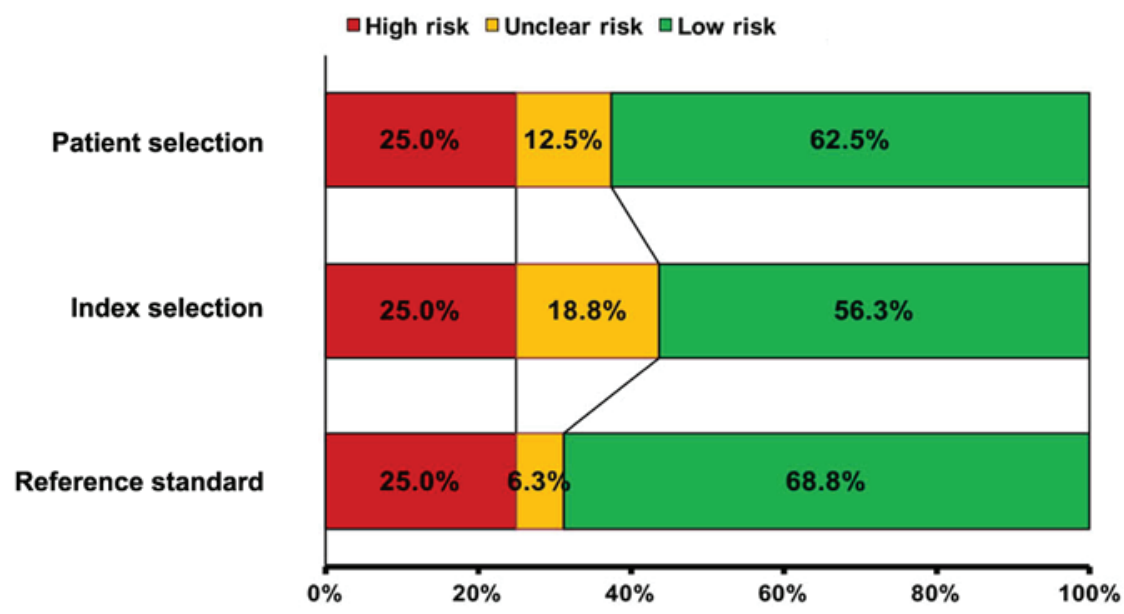

Figure 2. Risk of bias graph. The overall risk of bias was regarded as low in all qualified studies, in terms of the QUADAS-2 assessment. The reviewers' decisions about each risk of bias (A) and applicability concerns graph (B) presented as percentages across selected studies.

IL-10R, IL-17 and IL-23 polymorphisms. Also, the association between the type of each allele polymorphisms of $\mathrm{G}: \mathrm{A}, \mathrm{G}: \mathrm{C}$, $\mathrm{T}: \mathrm{C}$ and ethnicity, genotyping methods, IL type and control reference were measured as subgroup analysis.

G:A polymorphisms and MM susceptibility. Table II shows the results of the meta-analysis for $\mathrm{G}: \mathrm{A}$ and $\mathrm{MM}$ in the three different genotypes GG vs. AA, GG vs. AG and AA vs. GA. The combined analysis of 14 studies indicated that GG/AA polymorphism was associated with a statistically significant improvement of $40.8 \%$ in MM, when compared with the control group $(\mathrm{OR}=1.14,95 \% \mathrm{CI}, 0.88-1.47, \mathrm{P}<0.05)$; suggesting that the over-expression of GG/AA polymorphism is a prognostic factor for MM (Fig. 3A). Also, the subtotal OR of GG/AG and AA/GA were 1.18 [95\% CI, 0.94-1.3; P=0.27 (Fig. 3B)] and 0.98 [95\% CI, 0.76-1.27; P=0.005 (Fig. 3C)], respectively. No significant coloration was found between IL-17Ars2275913 and IL-10R $\alpha$ rs2228055 polymorphism $(\mathrm{OR}=0.64,95 \% \mathrm{CI}, 0.48-1.33, \mathrm{P}=0.26$ and $\mathrm{OR}=0.72,95 \% \mathrm{CI}$, $0.62-1.83, \mathrm{P}=0.43$, respectively). Strikingly, the OR of GG/AA was notably different compared with other polymorphisms. Subgroup analyses was conducted according to ethnicity, genotyping methods, IL type and control reference (Fig. S1). Furthermore, the G:A polymorphism detected in the IL-6 promoter $(\mathrm{OR}=1.05,95 \% \mathrm{CI}, 0.78-1.44)$ is more accurate in $\mathrm{MM}$ samples of the Asian population $(\mathrm{OR}=1.24,95 \% \mathrm{CI}$, 0.92-1.74). The PCR-RFLP based methods are more valuable methods for the detection of the G:A polymorphism in MM samples $(\mathrm{OR}=1.18,95 \% \mathrm{CI}, 0.94-1.62, \mathrm{P}=0.002)$.

G:C polymorphisms and MM susceptibility. As shown in Fig. 4, based on heterogeneity, the dominant model GG/CC has an appropriate effect model in the detection of the MM. The results in Fig. 4 clearly show that the GG genotype for the IL-6 promoter and IL-1 $\beta$ would increase MM risk by approximately $81 \%$ compared with the CC genotype. Correspondingly, G:C polymorphism for IL-1 $\beta 1464 \mathrm{G}>\mathrm{C}$ and IL-6572G $>\mathrm{C}$ would increase MM risk (Table III). Meanwhile, the sub-analysis findings suggest that hospital-based samples were more accurate in the detection of the G:C polymorphism in MM patients 
Table II. Meta-analysis results for G:A gene polymorphism.

\begin{tabular}{|c|c|c|c|c|c|c|}
\hline \multirow{2}{*}{$\begin{array}{l}\text { Allele } \\
\text { GG vs. AA }\end{array}$} & \multicolumn{2}{|c|}{ Subgroup } & \multirow{2}{*}{$\begin{array}{c}\text { Number study } \\
10\end{array}$} & \multirow{2}{*}{$\begin{array}{c}\text { OR } \\
0.98\end{array}$} & \multirow{2}{*}{$\begin{array}{r}95 \% \mathrm{CI} \\
(0.77-1.25)\end{array}$} & \multirow{2}{*}{$\frac{\text { P-value }}{0.352}$} \\
\hline & Ethnicity & (C) & & & & \\
\hline & & (A) & 3 & 1.17 & $(0.82-1.68)$ & 0.465 \\
\hline & Method & Taq & 10 & 1.17 & $(0.80-1.70)$ & 0.017 \\
\hline & & PCR & 4 & 1.17 & $(0.84-1.63)$ & 0.675 \\
\hline & Source & $\mathrm{PB}$ & 12 & 1.25 & $(0.92-1.71)$ & 0.083 \\
\hline & & $\mathrm{HB}$ & 2 & 0.86 & $(0.63-1.17)$ & 0.398 \\
\hline & Gene & Interleukin-6 promoter & 4 & 1.43 & $(0.69-2.97)$ & 0.006 \\
\hline & & Interleukin-6 receptor & 3 & 1.37 & $(0.42-4.50)$ & 0.038 \\
\hline & & Interleukin-10 & 3 & 1.04 & $(0.72-1.50)$ & 0.893 \\
\hline & & Interleukin-10 receptor & 2 & 1.33 & $(0.87-2.02)$ & 0.631 \\
\hline & Overall & & 14 & 1.14 & $(0.88-1.47)$ & 0.056 \\
\hline \multirow[t]{11}{*}{ GG vs. AG } & Ethnicity & (C) & 10 & 1.09 & $(0.92-1.29)$ & 0.626 \\
\hline & & (A) & 3 & 1.41 & $(1.03-1.92)$ & 0.960 \\
\hline & Method & Taq & 10 & 1.03 & $(0.84-1.26)$ & 0.202 \\
\hline & & PCR & 4 & 1.37 & $(1.03-1.81)$ & 0.956 \\
\hline & Source & $\mathrm{PB}$ & 12 & 1.16 & $(0.95-1.41)$ & 0.223 \\
\hline & & HB & 2 & 1.00 & $(0.78-1.27)$ & 0.504 \\
\hline & Gene & Interleukin-6 promoter & 4 & 0.84 & $(0.62-1.14)$ & 0.150 \\
\hline & & Interleukin-6 receptor & 3 & 1.53 & $(1.03-2.26)$ & 0.767 \\
\hline & & Interleukin-10 & 3 & 1.12 & $(0.83-1.50)$ & 0.949 \\
\hline & & Interleukin-10 receptor & 2 & 1.36 & $(0.92-2.02)$ & 0.949 \\
\hline & Overall & & 14 & 1.11 & $(0.94-1.30)$ & 0.273 \\
\hline \multirow[t]{11}{*}{ GA vs. AA } & Ethnicity & (C) & 11 & 1.08 & $(0.88-1.32)$ & 0.373 \\
\hline & & (A) & 3 & 1.18 & $(0.83-1.67)$ & 0.318 \\
\hline & Method & Taq & 11 & 0.89 & $(0.62-1.26)$ & 0.002 \\
\hline & & PCR & 4 & 1.15 & $(0.85-1.55)$ & 0.492 \\
\hline & Source & $\mathrm{PB}$ & 13 & 0.92 & $(0.66-1.29)$ & 0.002 \\
\hline & & $\mathrm{HB}$ & 2 & 1.16 & $(0.88-1.53)$ & 0.732 \\
\hline & Gene & Interleukin-6 promoter & 5 & 0.60 & $(0.30-1.180)$ & 0.001 \\
\hline & & Interleukin-6 receptor & 3 & 1.14 & $(0.50-2.90)$ & 0.077 \\
\hline & & Interleukin-10 & 3 & 1.07 & $(0.77-1.50)$ & 0.972 \\
\hline & & Interleukin-10 receptor & 2 & 1.03 & $(0.71-1.49)$ & 0.631 \\
\hline & Overall & & 15 & 0.98 & $(0.76-1.27)$ & 0.005 \\
\hline
\end{tabular}

GG, AG, AA, homozygotes for the common allele, heterozygotes, and homozygotes for the rare allele, respectively. Controls deviate from Hardy-Weinberg equilibrium $\left(\chi^{2}, \mathrm{P}<0.05\right)$. Effect after correction for Hardy-Weinberg equilibrium deviation. C, Caucasian; A, Asian; PCR, polymerase chain reaction; Taq, Taqman-polymerase chain reaction; PB, population-based; HB, hospital-based.

$(\mathrm{OR}=1.02,95 \% \mathrm{CI}, 0.62-1.42, \mathrm{P}=0.001$; Fig. S2). Although, other subgroup analyses such as ethnicity, genotyping methods and IL type did not have any significant effect on MM prognosis and therefore they were ignored (Fig. S2).

T:C polymorphisms and MM susceptibility. Data from 12 studies on IL-1, -6 and -10 polymorphisms were pooled and analyzed for the detection of the T:C polymorphisms and MM susceptibility (Table IV). A high risk of MM was found in the heterozygous model (Fig. 5A) and dominant model (Fig. 5B) of the T:C polymorphisms (TC/CC: $\mathrm{OR}=1.37$, 95\% CI, 0.88-2.16, $\mathrm{P}=0.001$ and TT/CC: $\mathrm{OR}=1.26,95 \% \mathrm{CI}$, $0.77-2.06, \mathrm{P}=0.007)$. Moreover, sub-analysis results of the $\mathrm{T}: \mathrm{C}$ polymorphisms revealed a significant correlation between IL-1 $\beta$ polymorphism $(\mathrm{OR}=1.18,95 \% \mathrm{CI}, 0.66-1.89, \mathrm{P}=0.005)$ in hospital-based source samples $(\mathrm{OR}=1.82,95 \% \mathrm{CI}, 0.54-2.06$, $\mathrm{P}=0.073$ ) and $\mathrm{MM}$ risk (Fig. S3). There was no significant correlation between other subgroup analysis and MM risk in the T:C polymorphisms (data not shown).

C:A polymorphisms and MM susceptibility. Table V and Fig. 6 demonstrate the meta-analysis results of C:A polymorphisms. No significant association was identified between the overall MM risk and three polymorphism models, CC/AA, CC/AC and AC/AA in IL-6 (rs8192284) and IL-10 (rs1800872) receptors $(\mathrm{P}>0.05)$. In the stratified analyses by ethnicity, genotyping 


\section{A}

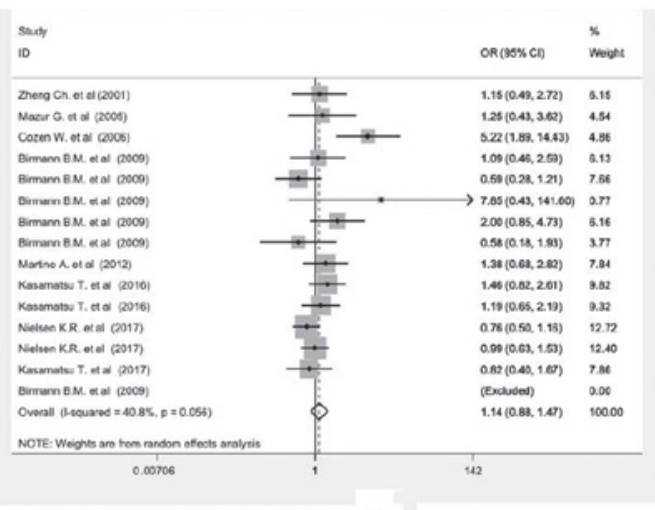

C $\stackrel{\sin }{\circ}$
B

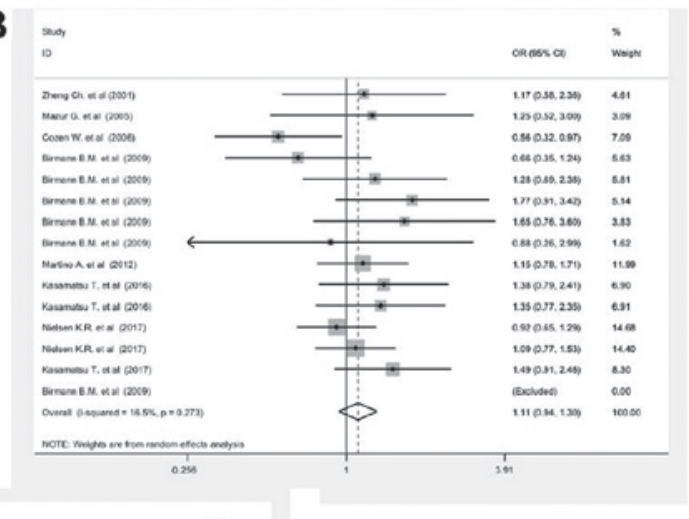

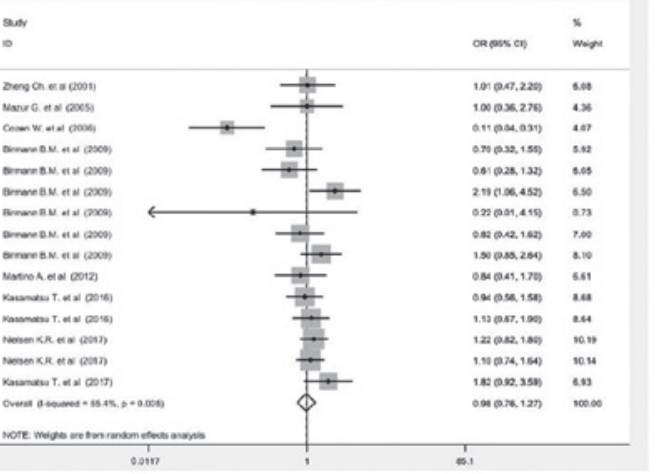

Figure 3. Forest plot of the association between G:A gene polymorphism and MM risk in the three difference genotype models: (A) GG vs. AA, (B) GG vs. AG, and (C) AA vs GA model. The size of each square is proportional to the percentage weight that each study contributed to the pooled odds ratio. Weights are from random effects analysis. OR, Odds ratio; CIs, confidence intervals.
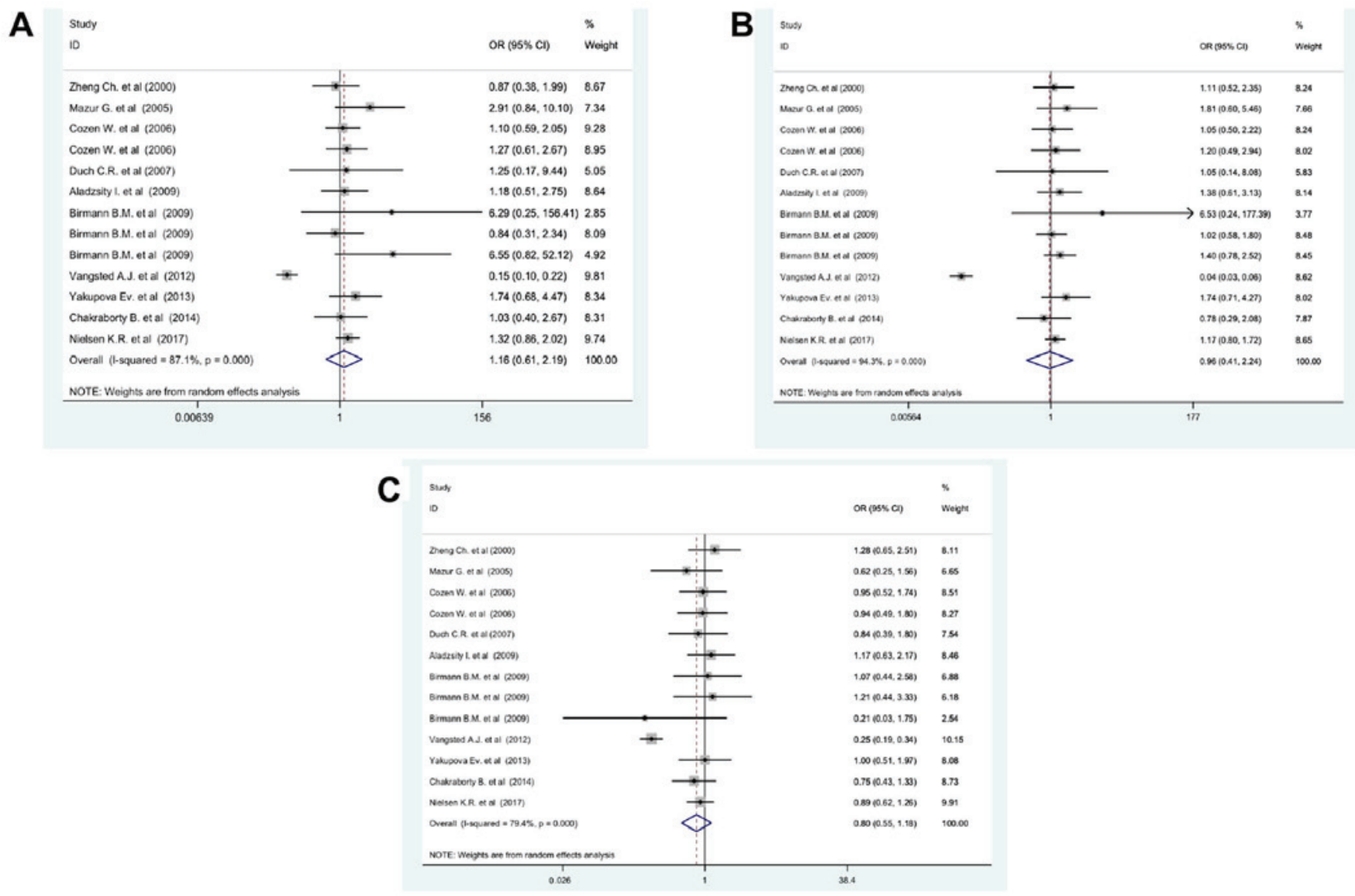

Figure 4. Forest plot of the association between G:C gene polymorphism and MM risk in the three difference genotype models: (A) GC vs. CC, (B) GC vs. CC, and (C) GC vs. GG model. The size of each square is proportional to the percentage weight that each study contributed to the pooled odds ratio. Weights are from random effects analysis. OR, Odds ratio; CIs, confidence intervals. 
Table III. Meta-analysis results for G:C gene polymorphism.

\begin{tabular}{|c|c|c|c|c|c|c|}
\hline \multirow{2}{*}{$\begin{array}{l}\text { Allele } \\
\text { GG vs. CC }\end{array}$} & \multicolumn{2}{|r|}{ Subgroup } & \multirow{2}{*}{$\begin{array}{c}\text { Number study } \\
9\end{array}$} & \multirow{2}{*}{$\frac{\mathrm{OR}}{1.21}$} & \multirow{2}{*}{$\begin{array}{c}95 \% \mathrm{CI} \\
(0.50-2.93)\end{array}$} & \multirow{2}{*}{$\begin{array}{r}\text { P-value } \\
0.001\end{array}$} \\
\hline & Ethnicity & (C) & & & & \\
\hline & & $(\mathrm{C}, \mathrm{M})$ & 3 & 1.17 & $(0.74-1.86)$ & 0.96 \\
\hline & Method & $\mathrm{Taq}$ & 11 & 1.21 & $(0.57-2.57)$ & 0.001 \\
\hline & Source & $\mathrm{PB}$ & 10 & 1.19 & $(0.51-2.80)$ & 0.001 \\
\hline & & $\mathrm{HB}$ & 3 & 1.25 & $(0.88-1.78)$ & 0.89 \\
\hline & Gene & Interleukin-6 promoter & 11 & 1.24 & $(0.97-1.58)$ & 0.9 \\
\hline & Overall & & 13 & 1.16 & $(0.61-2.19)$ & $>0.001$ \\
\hline \multirow[t]{7}{*}{ GC vs. $\mathrm{CC}$} & Ethnicity & (C) & 9 & 0.96 & $(0.31-2.92)$ & 0.001 \\
\hline & & $(\mathrm{C}, \mathrm{M})$ & 3 & 1.11 & $(0.63-1.92)$ & 0.97 \\
\hline & Method & $\mathrm{Taq}$ & 11 & 0.92 & $(0.34-2.47)$ & 0.001 \\
\hline & Source & PB & 10 & 0.94 & $(0.30-2.93)$ & 0.001 \\
\hline & & $\mathrm{HB}$ & 3 & 1.15 & $(0.83-1.59)$ & 0.67 \\
\hline & Gene & Interleukin-6 promoter & 11 & 1.18 & $(0.94-1.48)$ & 0.97 \\
\hline & Overall & & 13 & 0.96 & $(0.41-2.24)$ & $>0.001$ \\
\hline \multirow[t]{7}{*}{ GG vs. GC } & Ethnicity & (C) & 9 & 0.77 & $(0.45-1.33)$ & 0.001 \\
\hline & & $(\mathrm{C}, \mathrm{M})$ & 3 & 0.92 & $(0.63-1.34)$ & 0.96 \\
\hline & Method & Taq & 11 & 0.74 & $(0.48-1.13)$ & 0.001 \\
\hline & Source & $\mathrm{PB}$ & 10 & 0.76 & $(0.46-1.28)$ & 0.001 \\
\hline & & $\mathrm{HB}$ & 3 & 0.90 & $(0.69-1.18)$ & 0.58 \\
\hline & Gene & Interleukin-6 promoter & 11 & 0.94 & $(0.78-1.13)$ & 0.98 \\
\hline & Overall & & 13 & 0.81 & $(0.55-1.18)$ & $>0.001$ \\
\hline
\end{tabular}

GG, GC, CC, homozygotes for the common allele, heterozygotes, and homozygotes for the rare allele, respectively. Controls deviate from Hardy-Weinberg equilibrium $\left(\chi^{2}, \mathrm{P}<0.05\right)$. Effect after correction for Hardy-Weinberg equilibrium deviation. C, Caucasian; M, Mixed Afro-Americans; PB, population-based; HB, hospital-based.

methods, IL type and control reference no significant association were detected between C/A polymorphism and MM (Fig. S4). In the overall analysis, no significant association was detected between T:A and T:G polymorphism and MM under all three genetic models (data not shown).

Publication bias. Begg's and Egger's tests were used to estimate the publication bias of each allele polymorphism. The analysis was carried out by precluding a single study at a time (Fig. 7) (43). The shape of funnel plot and Egger's test provided no statistical evidence for publication bias of the $\mathrm{G}$ : $\mathrm{A}[\mathrm{t}=-0.92, \mathrm{P}=0.38,13$ study (Fig. 7A)], G:C [t=-2.02, P=0.0.069, 14 study (Fig. 7B)], T:C $[\mathrm{t}=-1.51, \mathrm{P}=0.162,12$ study (Fig. 7C) $]$ and $\mathrm{G}: \mathrm{A}[\mathrm{t}=-1.23, \mathrm{P}=0.31,5$ study (Fig. 7D)]. Likewise, Table SIII shows detailed publication bias of all investigated allele in three different models. P-values were revealed in Table SIII and no publication bias was found. Hence, there is no noticeable evidence for significant publication bias in our meta-analysis, which signifies that our meta-analysis results were stable and credible.

\section{Discussion}

To the best of our knowledge, this is the first comprehensive systematic review and meta-analysis study that has been conducted to identify the prognostics accuracy of all interleukin family gene polymorphisms in advanced MM patients. Data were extracted from a total of 16 publications that contained individuals carrying the GG genotype for IL-6 and IL-1 with an increased risk of MM by approximately 40.8 and $80.2 \%$ compared with the AA and CC genotypes. The results implied that a high MM risk was similar for IL-1 as well as IL-6; and revealed a significant association between their T:C polymorphism and MM risk. Furthermore, this study showed that patients with the heterozygous and dominant genotype of the T:C polymorphism have the highest MM risk. Notably, no significant association was found between the MM risk and C:A polymorphism in the IL-6 (rs8192284) and IL-10 (rs1800872) receptors (Fig. 6). Furthermore, hospital-based samples detected by PCR-RFLP methods are more attributable in identifying the interleukin family gene polymorphisms in MM patients. Keeping in mind the mentioned background, we tried to find significant correlations between ethnicity, IL type and MM sensitivity. We examined an overall sub-analysis of 2,597 patients and ORs for MM. Our results indicated that there was no significant association between IL gene polymorphism of the myeloma samples, ordered by ethnicity and type of IL family; which adversely affect cancer survival. Remarkably, we could not find any evidence about MM samples associated with sex and IL type. Our results clearly show that GG genotype for IL-6 promoter and IL-1 $\beta$ would increase MM risk by approximately $81 \%$ compared with the CC genotype $(\mathrm{R}=1.02,95 \% \mathrm{CI}, 0.62-1.42, \mathrm{P}=0.001)$.

It is well established that interleukin family polymorphisms may be a prognostic factor for survival in MM patients (20-23). Single-nucleotide polymorphisms in the promoter region of 
Table IV. Meta-analysis results for G:C gene polymorphism.

\begin{tabular}{|c|c|c|c|c|c|c|}
\hline \multirow{2}{*}{$\begin{array}{l}\text { Allele } \\
\text { TT vs. CC }\end{array}$} & \multicolumn{2}{|c|}{ Subgroup } & \multirow{2}{*}{$\frac{\text { Number study }}{7}$} & \multirow{2}{*}{$\frac{\mathrm{OR}}{0.95}$} & \multirow{2}{*}{$\begin{array}{c}95 \% \mathrm{CI} \\
(0.74-1.23)\end{array}$} & \multirow{2}{*}{$\begin{array}{c}\text { P-value } \\
0.19\end{array}$} \\
\hline & Source & $\mathrm{PB}$ & & & & \\
\hline & & $\mathrm{HB}$ & 5 & 0.92 & $(0.43-1.99)$ & 0.002 \\
\hline & Gene & Interleukin-1 $\beta$ & 4 & 0.91 & $(0.67-1.25)$ & 0.174 \\
\hline & & Interleukin-1 $\alpha$ & 2 & 0.49 & $(0.09-2.58)$ & 0.003 \\
\hline & & Interleukin-6 receptor & 3 & 1.06 & $(0.64-1.75)$ & 0.161 \\
\hline & & Interleukin-10 & 2 & 1.26 & $(0.52-3.04)$ & 0.280 \\
\hline & Overall & & 12 & 0.98 & $(0.73-1.30)$ & 0.007 \\
\hline \multirow[t]{7}{*}{ TT vs. TC } & Source & $\mathrm{PB}$ & 6 & 0.72 & $(0.46-1.13)$ & 0.025 \\
\hline & & $\mathrm{HB}$ & 5 & 2.39 & $(1.46-3.90)$ & 0.157 \\
\hline & Gene & Interleukin- $1 \beta$ & 4 & 1.28 & $(0.59-2.75)$ & 0.001 \\
\hline & & Interleukin-1 $\alpha$ & 2 & 2.39 & $(1.16-4.95)$ & 0.214 \\
\hline & & Interleukin-6 receptor & 3 & 0.90 & $(0.24-3.33)$ & 0.006 \\
\hline & & Interleukin-10 & 2 & 0.99 & $(0.34-2.89)$ & 0.180 \\
\hline & Overall & & 12 & 1.26 & $(0.77-2.06)$ & 0.001 \\
\hline \multirow[t]{7}{*}{ TC vs. CC } & Source & PB & 6 & 0.768 & $(0.63-0.93)$ & 0.391 \\
\hline & & HB & 5 & 2.693 & $(1.15-6.33)$ & 0.001 \\
\hline & Gene & Interleukin-1 $\beta$ & 4 & 1.342 & $(0.71-2.54)$ & 0.001 \\
\hline & & Interleukin- $1 \alpha$ & 2 & 5.181 & $(1.99-13.43)$ & 0.078 \\
\hline & & Interleukin-6 receptor & 3 & 0.81 & $(0.37-1.78)$ & 0.090 \\
\hline & & Interleukin-10 & 2 & 0.851 & $(0.634-1.14)$ & 0.001 \\
\hline & Overall & & 11 & 1.37 & $(0.88-2.13)$ & 0.001 \\
\hline
\end{tabular}

TT, TC, CC, homozygotes for the common allele, heterozygotes, and homozygotes for the rare allele, respectively. Controls deviate from Hardy-Weinberg equilibrium $\left(\chi^{2}, \mathrm{P}<0.05\right)$. Effect after correction for Hardy-Weinberg equilibrium deviation. PB, population-based; HB, hospital-based.

IL-1, -6 and -10 are associated with multiple inflammatory and immune-mediated diseases, including cancer, Crohn's disease, ulcerative colitis and type 1 diabetes $(44,45)$. As a major pro-inflammatory cytokine, IL-6 and IL-1 could mediate chemokine, adhesion molecule expression, recruit monocytes and macrophages to release a large number of growth factors and cytokines (20). Many studies show that overexpression of the pro-inflammatory interleukin is a significant prognostic biomarker in patients with MM (25). In the present meta-analysis, the $\mathrm{G}: \mathrm{C}$ polymorphisms (mainly GG genotype) in IL-6-572G $>$ C and IL-6-174G $>C$ are associated with an increased susceptibility to MM. Therefore, both tagging SNPs of IL-6rs1800795 and IL-6rs1800797 are most reliable and could be used for the prediction of MM progression $(23,24)$. These SNPs located in the promoter region of the IL- 6 gene may regulate IL-6 production and correlate with the susceptibility of some other cancers (23,25). Recently, Li et al, (2017) reported that IL-6 may be a potential biomarker for MM diagnosis (18). It suggested that IL-6 SNPs are very useful prognostic biomarkers in clinical usage and could be truly specific in prognosis of a particular cancer type (18). These results are completely consistent with other investigations (46-48).

IL- $1 \alpha$ and IL-1 $\beta$, two members of IL-1, have a common receptor with shared SNPs (IL- $1 \alpha-889 \mathrm{C}>\mathrm{T}$ and IL-1 $\beta-3737 \mathrm{C}>\mathrm{T}$ ) (49). Our results show that C:T polymorphisms of the IL- $1 \alpha-889 \mathrm{C}>\mathrm{T}$ and IL- $1 \beta-3737 \mathrm{C}>\mathrm{T}$ were associated with MM risk. IL-10 is one of the well-investigated pro-inflammatory cytokines (34). It is documented that IL-10-592G/A and IL-10-1,082G>A SNPs are located in the negative and positive regulatory sequence of the promoter region, respectively (34). The IL-10 gene with -592 (C) or $-1,082(\mathrm{G})$ is associated with a high expression of IL-10, and it has a low expression with -592 (A) or -1,082 (A). Our results indicate that the $\mathrm{C}$ allele of IL-10-592 has no significant association with $\mathrm{MM}$ susceptibility under the three allele model, $\mathrm{CC} / \mathrm{AA}, \mathrm{CC} / \mathrm{AC}$ and $\mathrm{AC} / \mathrm{AA}^{18}$. In contrast, our cumulative results indicate that IL-10-1082G $>\mathrm{A}$ is found to be associated with MM risk ( $\mathrm{R}=1.18,95 \% \mathrm{CI}, 0.94-1.3)$.

Recently, Sultana et al, (2018) (48) indicate that the C allele of IL-1 $\alpha-889$ is higher in MM patients than in controls. Similarly, Ziakas et al, (2013) (50) show that the G allele of IL-1 $3-1464 G>C$ was significantly associated with MM in an Asian population. Of course, the discrepancies between the mentioned studies may also be due to small sample size and ethnic differences.

Despite these competent studies, the conventional formation and balancing of interleukin family gene polymorphisms in the interconnecting angiogenesis of the human MM neoplasms are not well-defined yet (45). Location variety and heterogenic morphology of MM tumors that have a close relationship with the interleukin family SNPs, represented noteworthy challenge for oncologist. With these presuppositions, the present investigation allows us to acquire a better understanding of the prognostic role of interleukin family gene SNPs in MM patients by using statistical approaches. Conversely, the correlation 
Table V. Meta-analysis results for C:A gene polymorphism.

\begin{tabular}{|c|c|c|c|c|c|c|}
\hline \multirow{2}{*}{$\begin{array}{l}\text { Allele } \\
\text { CC vs. AA }\end{array}$} & \multicolumn{2}{|c|}{ Subgroup } & \multirow{2}{*}{$\begin{array}{c}\text { Number study } \\
4\end{array}$} & \multirow{2}{*}{$\frac{\text { OR }}{1.79}$} & \multirow{2}{*}{$\begin{array}{c}95 \% \mathrm{CI} \\
(1.17-2.75)\end{array}$} & \multirow{2}{*}{$\begin{array}{r}\text { P-value } \\
0.462\end{array}$} \\
\hline & Source & PB & & & & \\
\hline & & HB & 2 & 1.35 & $(0.72-2.53)$ & 0.743 \\
\hline & Gene & Interleukin-6 receptor & 3 & 2.11 & $(1.29-3.46)$ & 0.730 \\
\hline & & Interleukin-10 & 3 & 1.26 & $(0.76-2.10)$ & 0.759 \\
\hline & Ethnicity & (C) & 5 & 1.74 & $(1.18-2.57)$ & 0.614 \\
\hline & Method & $\mathrm{Taq}$ & 4 & 1.80 & $(1.17-2.75)$ & 0.462 \\
\hline & Overall & & 6 & 1.64 & $(1.15-2.33)$ & 0.666 \\
\hline \multirow[t]{7}{*}{ CC vs. AC } & Source & PB & 4 & 1.56 & $(0.80-3.04)$ & 0.062 \\
\hline & & HB & 2 & 1.06 & $(0.57-1.97)$ & 0.816 \\
\hline & Gene & Interleukin-6 receptor & 3 & 2.05 & $(1.28-3.28)$ & 0.373 \\
\hline & & Interleukin-10 & 3 & 0.95 & $(0.49-1.84)$ & 0.211 \\
\hline & Ethnicity & (C) & 5 & 1.50 & $(0.86-2.59)$ & 0.094 \\
\hline & Method & Taq & 4 & $1.56 \mathrm{~s}$ & $(0.80-3.04)$ & 0.062 \\
\hline & Overall & & 6 & 1.40 & $(0.87-2.25)$ & 0.107 \\
\hline \multirow[t]{7}{*}{ AC vs. AA } & Source & PB & 4 & 0.93 & $(0.72-1.21)$ & 0.362 \\
\hline & & HB & 2 & 0.79 & $(0.54-1.14)$ & 0.869 \\
\hline & Gene & Interleukin-6 receptor & 3 & 0.94 & $(0.66-1.34)$ & 0.7 \\
\hline & & Interleukin-10 & 3 & 0.82 & $(0.59-1.16)$ & 0.228 \\
\hline & Ethnicity & (C) & 5 & 0.91 & $(0.72-1.14)$ & 0.463 \\
\hline & Method & $\mathrm{Taq}$ & 4 & 0.93 & $(0.72-1.21)$ & 0.362 \\
\hline & Overall & & 6 & 0.89 & $(0.72-1.09)$ & 0.578 \\
\hline
\end{tabular}

AA, AC, CC, homozygotes for the common allele, heterozygotes, and homozygotes for the rare allele, respectively. Controls deviate from Hardy-Weinberg equilibrium $\left(\chi^{2}, \mathrm{P}<0.05\right)$. Effect after correction for Hardy-Weinberg equilibrium deviation. PB, population-based; HB, hospital-based; C, Caucasian; Taq, Taqman- polymerase chain reaction.

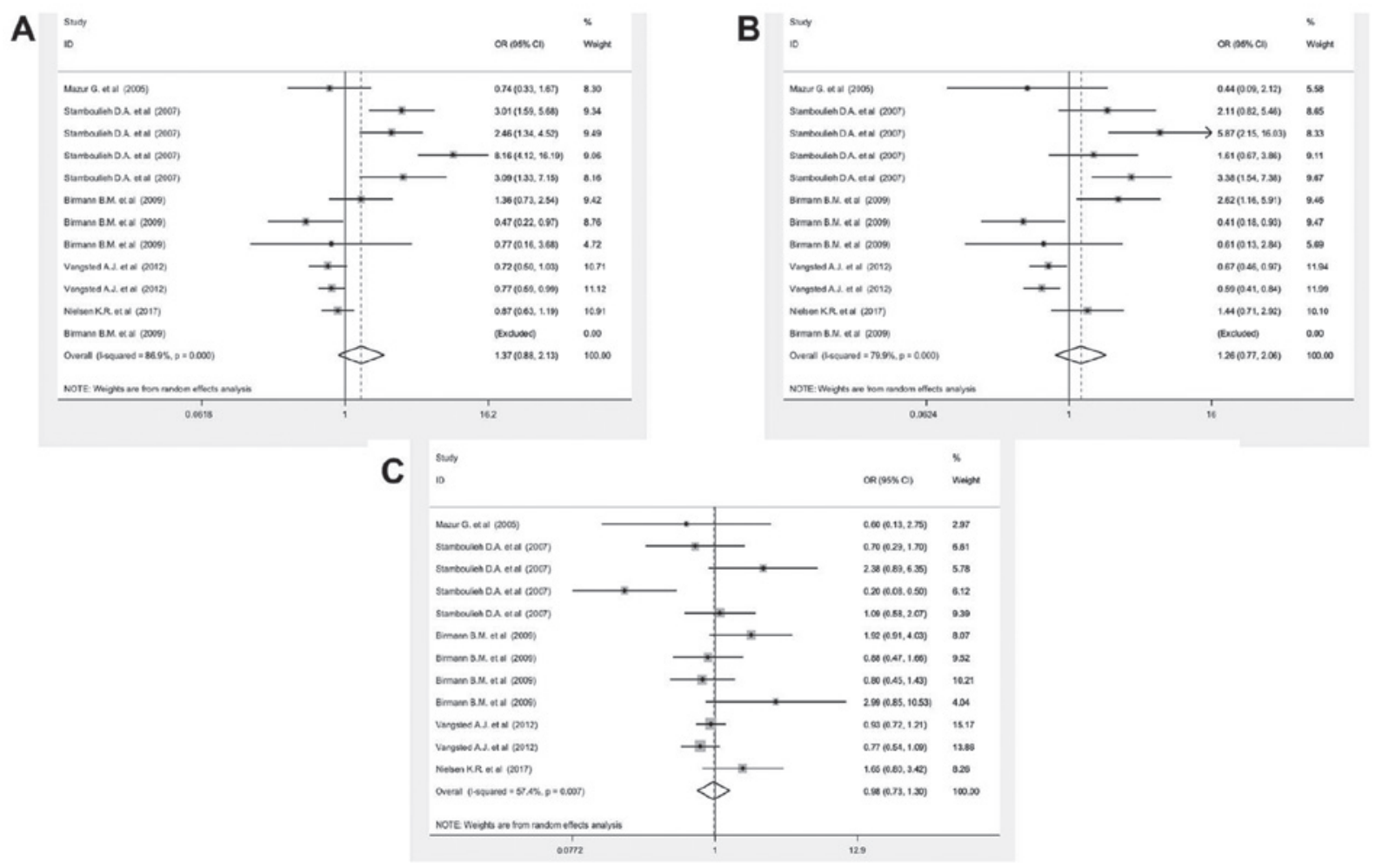

Figure 5. Forest plot of the association between T:C gene polymorphism and MM risk in the three difference genotype models: (A) TC vs. CC, (B) TT vs. CC, and (C) TT vs. TC model. The size of each square is proportional to the percentage weight that each study contributed to the pooled odds ratio. Weights are from random effects analysis. OR, Odds ratio; CIs, confidence intervals. 


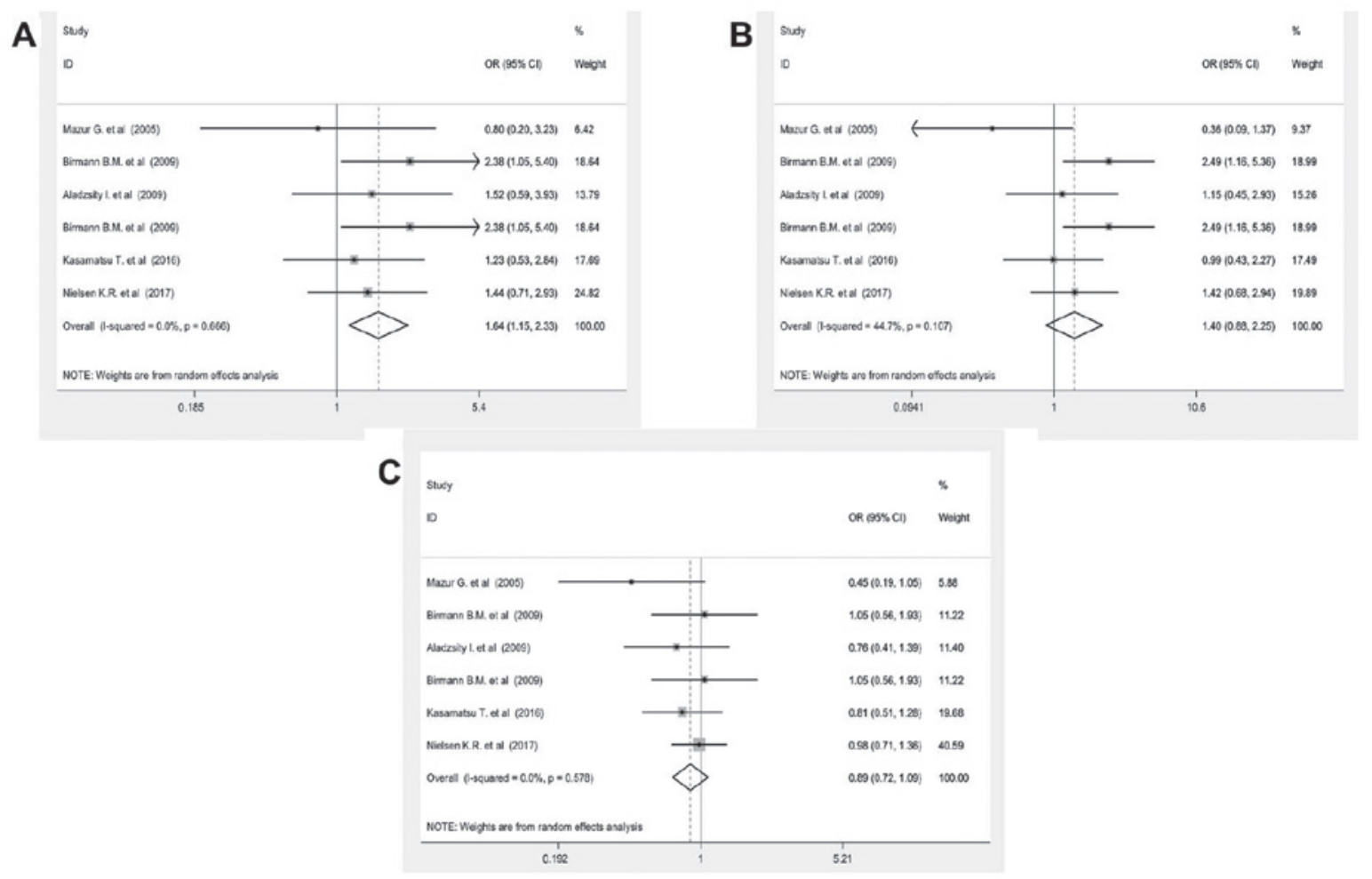

Figure 6. Forest plot of the association between C:A gene polymorphism and MM risk in the three difference genotype models: (A) CC vs. AA, (B) CC vs. AC, and (C) AC vs. AA model. The size of each square is proportional to the percentage weight that each study contributed to the pooled odds ratio. Weights are from random effects analysis. OR, Odds ratio; CIs, confidence intervals.

A

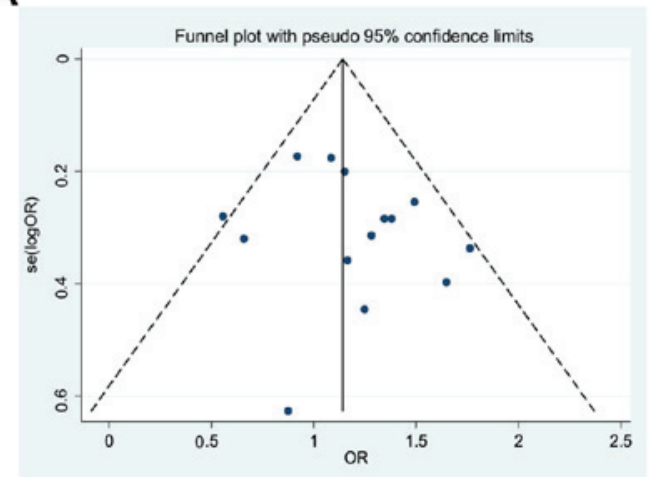

C

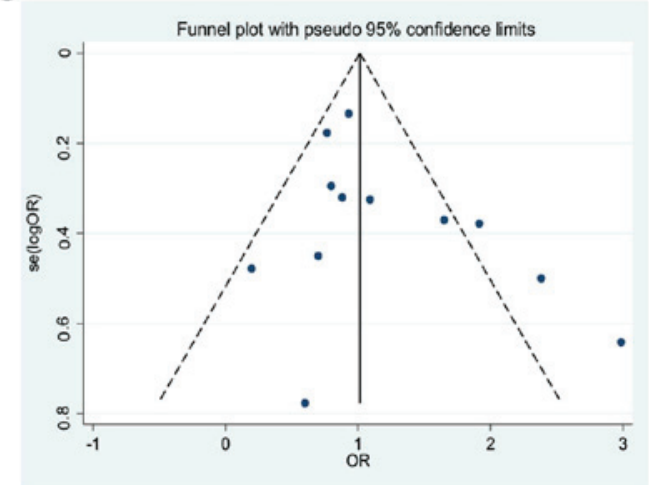

B

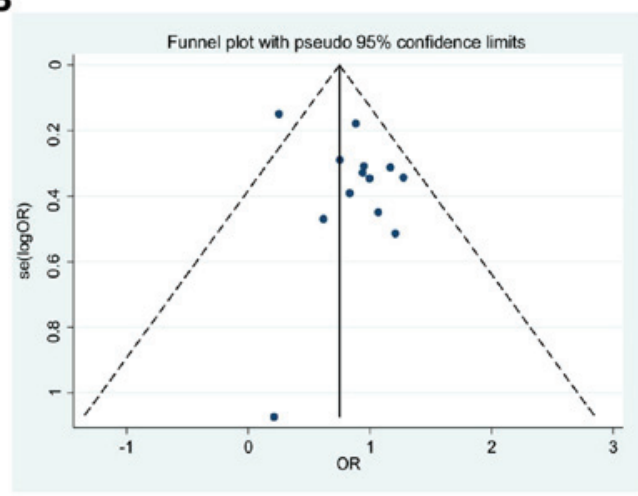

D

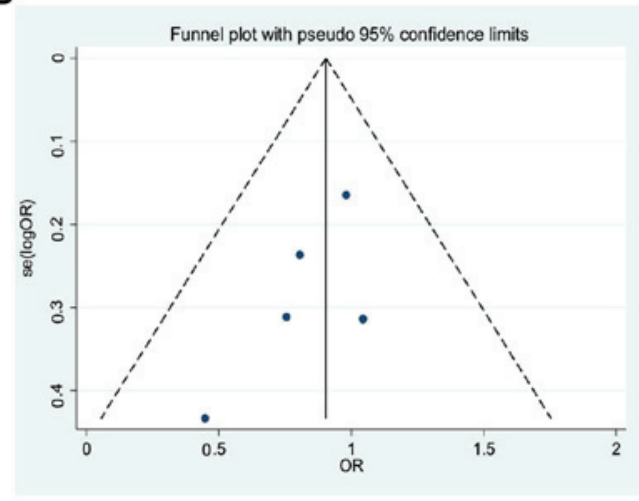

Figure 7. Contour-enhanced funnel plots for the detection of a publication bias of the G:A (A); G:C (B); T:C (C); and G:A (D). All enrolled 16 studies represent by each point for the specified association, individually. These plots indicate that some studies were in significant areas where $\mathrm{P}<0.01$ (solid lines) and where $\mathrm{P}=0.01-<0.05$ (dashed lines); other studies were in the non-significant area (the area between the two dashed lines). Solid triangles refer to included studies and $\mathrm{X}$ 's refer to filled studies. The vertical axis represents standard error of logarithmic HR and the horizontal axis represents the HRs limits. HR, hazard ratio. 
between the interleukin gene SNPs and the survival of cancer patients are controversial or inconclusive. On the other hand, several published meta-analyses have been concerned with the evaluation of the dissimilarity in interleukin family gene polymorphisms related to the prognosis of cancer $(20-25,51)$. The overall findings help us describe the possible prognostic role of the interleukin polymorphism in MM progress, and identify a novel therapeutic target of MM progression. We tried to include all the possible literature on the relationship between interleukin polymorphism and MM risk and to obtain the maximum sample size and comprehensive results. Although, it should be noted that many future studies are needed for the description of the molecular mechanisms, because at the moment the published proof is scant. Unavoidably, there are still some limitations: i) A few studies and a small sample size have demonstrated correlations between interleukin gene family polymorphism and MM prognosis; ii) we only included the papers in English language, while published papers in other languages, especially Chinese and Russian were ignored; iii) poor homogeneous distribution and population based on subgroup parameters existed in some studies; iv) the occurrence and development of MM are on the basis of many hereditary and environmental factors as well as the interaction between them, but these factors and the pathological states of MM were not considered in this meta-analysis; and v) the low quality of some included studies led to meta-analysis results that were based on unadjusted estimates, because some studies did not provide detailed information to calculate the adjusted estimates. Besides, a lot of confounding factors were not controlled or reported in biased statistical results. We like to point out that future well-accepted clinical studies with larger samples sizes, systematized protocols and more homogenized populations would be needed to fully investigate the prognostic potential of each SNP in interleukin gene family of MM patients.

In conclusion, the present meta-analysis shows that $\mathrm{G}: \mathrm{C}$ polymorphism of the IL-1 $14464 \mathrm{G}>\mathrm{C}$ and IL-6572G $>\mathrm{C}$ would increase MM risk. However, it has been determined that there is a significant association between MM risk and C:T polymorphism in IL- $1 \alpha-889 \mathrm{C}>\mathrm{T}$ and IL-1 $\beta-3737 \mathrm{C}>\mathrm{T}$. Additionally, hospital-based source samples are more accurate and attributable in the detection of interleukin family gene polymorphisms in Asian patients with MM, by using the PCR-RFLP method. These SNP loci may be appropriate biomarkers for gene screening and an effective adjuvant therapeutic strategy in prognostics of MM patients.

\section{Acknowledgements}

Not applicable.

\section{Funding}

This study was supported in part by National Natural Science and Technology Fund Project (grant no. 81450030) and Sichuan Provincial Department of Education major training project (grant no. 14CZ0017).

\section{Availability of data and materials}

The datasets used and/or analyzed during the present study are available from the corresponding author on reasonable request.

\section{Authors' contributions}

$\mathrm{CH}$ and MNS were in charge of the idea and study designation. II, SN, and CY searched and collected data. FL and SL performed data analysis. MNS and II wrote the manuscript and were in charge of language revision. SN edited the paper. All authors read and approved the final manuscript.

\section{Ethics approval and consent to participate}

The present meta-analysis was approved by an independent Ethics Committee/institutional review board at Southwest Medical University, Department of Hematology (Luzhou, China). This investigation was carried out by following recommendations of the Preferred Reporting Items for Systematic Reviews and Meta-Analysis (PRISMA).

\section{Patient consent for publication}

Not applicable.

\section{Competing interests}

The authors declare that they have no competing interests.

\section{References}

1. Siegel RL, Miller KD and Jemal A: Cancer statistics, 2017. CA Cancer J Clin 67: 7-30, 2017.

2. Shi H, Chen Z, Xie J and Chen N: The prevalence and management of multiple myeloma-induced kidney disease in China. Kidney Dis (Basel) 1: 235-40, 2016.

3. Holstein SA and McCarthy PL: Immunomodulatory drugs in multiple myeloma: Mechanisms of action and clinical experience. Drugs 77: 505-520, 2017.

4. Huang QC and Ding JY: Research advance in light Chain escape of multiple myeloma-Review. Zhongguo Shi Yan Xue Ye Xue Za Zhi 25: 1833-1836, 2017 (In Chinese).

5. T V, V G and A ND: Multiple myeloma index for risk of infection. J Cancer 9: 2211-2214, 2018.

6. Chen YF and Lu YL: Survival and prognosis analysis of 57 patients with multiple myeloma. Zhongguo Shi Yan Xue Ye Xue Za Zhi 25: 1436-1443, 2017 (In Chinese).

7. Curado MP, Oliveira MM, Silva DRM and Souza DLB: Epidemiology of multiple myeloma in 17 Latin American countries: An update. Cancer Med 7: 2101-2108, 2018.

8. Tang CH, Liu HY, Hou HA, Qiu H, Huang KC, Siggins S, Rothwell LA and Liu Y: Epidemiology of multiple myeloma in Taiwan, a population based study. Cancer Epidemiol 55: 136-141, 2018.

9. Soekojo CY, de Mel S, Ooi M, Yan B and Chng WJ: Potential clinical application of genomics in multiple myeloma. Int $\mathrm{J}$ Mol Sci 9: pii: E1721, 2018.

10. Willenbacher W, Seeber A, Steiner N, Willenbacher E, Gatalica Z, Swensen J, Kimbrough J and Vranic S: Towards Molecular profiling in multiple myeloma: A literature review and early indications of its efficacy for informing treatment strategies. Int J Mol Sci 19: pii: E2087, 2018.

11. Jupe S, Ray K, Roca CD, Varusai T, Shamovsky V, Stein L, D'Eustachio P and Hermjakob H: Interleukins and their signaling pathways in the Reactome biological pathway database. J Allergy Clin Immunol 141: 1411-1416, 2018.

12. Yasui H, Hideshima T, Richardson PG and Anderson KC: Novel therapeutic strategies targeting growth factor signalling cascades in multiple myeloma. Br J Haematol 132: 385-397, 2006.

13. Naka T, Nishimoto $\mathrm{N}$ and Kishimoto T: The paradigm of IL-6: From basic science to medicine. Arthritis Res 4 (Suppl 3): S233-S242, 2002.

14. Ishikawa $\mathrm{H}$, Tsuyama $\mathrm{N}$ and Kawano MM: Interleukin-6-induced proliferation of human myeloma cells associated with CD45 molecules. Int J Hematol 78: 95-105, 2003. 
15. Liu FT, Zhu PQ, Ou YX, Liu WW, Xia GF and Luo HL: Positive association between IL-16 rs1131445 polymorphism and cancer risk: A meta-analysis. Minerva Med 107: 84-91, 2016.

16. Hong JB, Zuo W, Wang AJ and Lu NH: Helicobacter pylori infection synergistic with IL-1 $\beta$ gene polymorphisms potentially contributes to the carcinogenesis of gastric cancer. Int J Med Sci 13: 298-303, 2016

17. Kasamatsu T, Kimoto M, Takahashi N, Minato Y, Gotoh N, Takizawa M, Matsumoto M, Sawamura M, Yokohama A, Handa H, et al: IL17A and IL23R gene polymorphisms affect the clinical features and prognosis of patients with multiple myeloma. Hematol Oncol 36: 196-201, 2018.

18. Li Y, Du Z, Wang X, Wang G and Li W: Association of IL-6 promoter and receptor polymorphisms with multiple myeloma risk: A systematic review and meta-analysis. Genet Test Mol Biomarkers 20: 587-596, 2016.

19. Banu C, Moise A, Arion CV, Coriu D, Tănase A and Constantinescu I: Cytokine gene polymorphisms support diagnostic monitoring of Romanian multiple myeloma patients. J Med Life 4: 264-268, 2011.

20. Birmann BM, Tamimi RM, Giovannucci E, Rosner B, Hunter DJ, Kraft P, Mitsiades C, Anderson KC and Colditz GA: Insulin-like growth factor-1- and interleukin-6-related gene variation and risk of multiple myeloma. Cancer Epidemiol Biomarkers Prev 18: 282-288, 2009 .

21. Vangsted AJ, Klausen TW, Ruminski W, Gimsing P, Andersen NF, Gang AO, Abildgaard N, Knudsen LM, Nielsen JL, Gregersen H and Vogel U: The polymorphism IL-1beta T-31C is associated with a longer overall survival in patients with multiple myeloma undergoing auto-SCT. Bone Marrow Transplant 43: 539-545, 2009.

22. Abazis-Stamboulieh D, Oikonomou P, Papadoulis N, Panayiotidis P, Vrakidou E and Tsezou A: Association of interleukin-1A, interleukin-1B and interleukin-1 receptor antagonist gene polymorphisms with multiple myeloma. Leuk Lymphoma 48 2196-2203, 2007.

23. Mazur G, Bogunia-Kubik K, Wróbel T, Karabon L, Polak M, Kuliczkowski K and Lange A: IL-6 and IL-10 promoter gene polymorphisms do not associate with the susceptibility for multiple myeloma. Immunol Lett 96: 241-246, 2005.

24. Cozen W, Gebregziabher M, Conti DV, Van Den Berg DJ, Coetzee GA, Wang SS, Rothman N, Bernstein L, Hartge P, Morhbacher A, et al: Interleukin-6-related genotypes, body mass index, and risk of multiple myeloma and plasmacytoma. Cancer Epidemiol Biomarkers Prev 15: 2285-2291, 2006.

25. Iakupova EV, Grinchuk OV, Kalimullina DKh, Bakirov BA, Galimova RR, Makarova OV, Khusnutdinova EK and Viktorova TV: Molecular genetic analysis of the interleukin 6 and tumor necrosis factor alpha gene polymorphisms in multiple myeloma. Mol Biol (Mosk) 37: 420-424, 2003 (In Russian).

26. Shamseer L, Moher D, Clarke M, Ghersi D, Liberati A, Petticrew M, Shekelle P and Stewart LA; PRISMA-P Group: Preferred reporting items for systematic review and meta-analysis protocols (PRISMA-P) 2015: Elaboration and explanation. BMJ 350: g7647, 2015

27. Richardson WS, Wilson MC, Nishikawa J and Hayward RS: The well-built clinical question: A key to evidence-based decisions. ACP J Club 123: A12-A13, 1995

28. Stang A: Critical evaluation of the Newcastle-Ottawa scale for the assessment of the quality of nonrandomized studies in meta-analyses. Eur J Epidemiol 25: 603-605, 2010.

29. Whiting PF, Rutjes AW, Westwood ME, Mallett S, Deeks JJ, Reitsma JB, Leeflang MM, Sterne JA and Bossuyt PM; QUADAS-2 Group: QUADAS-2: A revised tool for the quality assessment of diagnostic accuracy studies. Ann Intern Med 155: 529-536, 2011

30. Higgins JP, Thompson SG, Deeks JJ and Altman DG: Measuring inconsistency in meta-analyses. BMJ 327: 557-560, 2003.

31. Heavener T and Vassar M: A review of publication bias in the gastroenterology literature. Indian J Gastroenterol 37: 58-62, 2018.

32. Egger M, Davey Smith G, Schneider M and Minder C: Bias in meta-analysis detected by a simple, graphical test. BMJ 315: 629-634, 1997.

33. Zheng C, Huang DR, Bergenbrant S, Sundblad A, Osterborg A, Björkholm M, Holm G and Yi Q: Interleukin 6, tumour necrosis factor alpha, interleukin 1beta and interleukin 1 receptor antagonist promoter or coding gene polymorphisms in multiple myeloma. Br J Haematol 109: 39-45, 2000.

34. Zheng C, Huang D, Liu L, Wu R, Bergenbrant Glas S, Osterborg A, Bjorkholm M, Holm G, Yi Q and Sundblad A: Interleukin-10 gene promoter polymorphisms in multiple myeloma. Int J Cancer 95: 184-188, 2001
35. Aladzsity I, Kovács M, Semsei A, Falus A, Szilágyi A, Karádi I, Varga G, Füst G and Várkonyi J: Comparative analysis of IL6 promoter and receptor polymorphisms in myelodysplasia and multiple myeloma. Leuk Res 33: 1570-1573, 2009.

36. Vangsted AJ, Nielsen KR, Klausen TW, Haukaas E, Tjønneland A and Vogel U: A functional polymorphism in the promoter region of the IL1B gene is associated with risk of multiple myeloma. Br J Haematol 158: 515-518, 2012

37. Nielsen KR, Rodrigo-Domingo M, Steffensen R, Baech J, Bergkvist KS, Oosterhof L, Schmitz A, Bødker JS, Johansen P, Vogel U, et al: Interactions between SNPs affecting inflammatory response genes are associated with multiple myeloma disease risk and survival. Leuk Lymphoma 58: 2695-2704, 2017.

38. Martino A, Buda G, Maggini V, Lapi F, Lupia A, Di Bello D, Orciuolo E, Galimberti S, Barale R, Petrini M and Rossi AM: Could age modify the effect of genetic variants in IL6 and TNF- $\alpha$ genes in multiple myeloma? Leuk Res 36: 594-597, 2012.

39. Chakraborty B, Vishnoi G, Gowda SH and Goswami B: Interleukin-6 gene-174 G/C promoter polymorphism and its association with clinical profile of patients with multiple myeloma. Asia Pac J Clin Oncol 13: e402-e407, 2017.

40. Kasamatsu T, Saitoh T, Ino R, Gotoh N, Mitsui T, Shimizu H, Matsumoto M, Sawamura M, Yokohama A, Handa $\mathrm{H}$, et al: Polymorphism of IL-10 receptor $\beta$ affects the prognosis of multiple myeloma patients treated with thalidomide and/or bortezomib. Hematol Oncol 35: 711-718, 2017.

41. Duch CR, Figueiredo MS, Ribas C, Almeida MS, Colleoni GW and Bordin JO: Analysis of polymorphism at site $-174 \mathrm{G} / \mathrm{C}$ of interleukin-6 promoter region in multiple myeloma. Braz J Med Biol Res 40: 265-267, 2007.

42. Stephens OW, Zhang Q, Qu P, Zhou Y, Chavan S, Tian E, Williams DR, Epstein J, Barlogie B and Shaughnessy JD Jr: An intermediate-risk multiple myeloma subgroup is defined by sIL-6r: Levels synergistically increase with incidence of SNP rs2228145 and 1q21 amplification. Blood 119: 503-512, 2012.

43. Tobias A: Assessing the influence of a single study in the meta-analysis estimate. Stata Techn Bull 47: 15-17, 1999.

44. Dukat-Mazurek A, Bieniaszewska M,Hellmann A,Moszkowska G and Trzonkowski P: Association of cytokine gene polymorphisms with the complications of allogeneic haematopoietic stem cell transplantation. Hum Immunol 78: 672-683, 2017.

45. Lu Y, Gu J, Lu H, Zhu Q, Zhang F, Wang X, Lu L and Zhang C: Association between IL-17A +197 G/A polymorphism and cancer risk: A meta-analysis. Genet Test Mol Biomarkers 20: 24-30, 2016.

46. Galicia JC, Tai H, Komatsu Y, Shimada Y, Akazawa K and Yoshie H: Polymorphisms in the IL-6 receptor (IL-6R) gene: Strong evidence that serum levels of soluble IL-6R are genetically influenced. Genes Immun 5: 513-516, 2004.

47. Fishman D, Faulds G, Jeffery R, Mohamed-Ali V, Yudkin JS, Humphries S and Woo P: The effect of novel polymorphisms in the interleukin-6 (IL-6) gene on IL-6 transcription and plasma IL-6 levels, and an association with systemic-onset juvenile chronic arthritis. J Clin Invest 102: 1369-1376, 1998.

48. Sultana Z, Bankura B, Pattanayak AK, Sengupta D, Sengupta M, Saha ML, Panda CK and Das M: Association of Interleukin-1 beta and tumor necrosis factor-alpha genetic polymorphisms with gastric cancer in India. Environ Mol Mutagen 59: 653-667, 2018.

49. Demeter J, Messer G, Ramisch S, Mee JB, di Giovine FS, Schmid M, Herrmann F and Porzsolt F: Polymorphism within the second intron of the IL-1 receptor antagonist gene in patients with hematopoietic malignancies. Cytokines Mol Ther 2: 239-242, 1996.

50. Ziakas PD, Karsaliakos P, Prodromou ML and Mylonakis E: Interleukin-6 polymorphisms and hematologic malignancy: A re-appraisal of evidence from genetic association studies. Biomarkers 18: 625-631, 2013

51. Singh PK, Chandra G, Bogra J, Gupta R, Kumar V, Jain A, Hussain SR, Mahdi AA and Ahmad MK: Association of interleukin-6 genetic polymorphisms with risk of OSCC in Indian population. Meta Gene 4: 142-51, 2015.

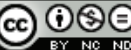

This work is licensed under a Creative Commons Attribution-NonCommercial-NoDerivatives 4.0 International (CC BY-NC-ND 4.0) License. 